\title{
Health, an enduring theme for urban planning
}

\author{
Marco MAREGGI, DAStU/Politecnico di Milano, Italy \\ Luca LAZZARINI, DAStU/Politecnico di Milano, Italy
}

\begin{abstract}
The contribution investigates the relationship between health and planning and describes the impact of the pandemic on the resurgence of health as a topic able to orient urban planning. The first section describes some significant episodes in the planning history of two European countries, England and Italy, to demonstrate that issues of sanitation and health have guided the transformation of cities and have shaped modern town planning since its origins, dated back in late XIX century. In the second section, we highlight a resurgence in the last 30-40 years of an interest in well-being and quality of life by planning policies in Europe thanks to some international movements, the Time of the City and the Healthy Cities. In the section 3 we examine the contribution of cities in reacting to the Covid-19 pandemic by presenting a number of planning strategies, policies and actions implemented by local governments, that have been experimenting with new forms of urban proximity. The final section discusses the extent to which the global pandemic has brought innovations to the debate regarding the relationship between health and planning.
\end{abstract}

\section{Keywords}

Health, Wellbeing, Pandemic, Proximity

\section{Introduction}

The contribution investigates the relationship between health and planning and describes the impact of the pandemic on the resurgence of health as a topic able to orient planning policies and strategies. Since 2020, due to the Covid-19 pandemic, there has been a growing academic and policy interest to health in the field of planning (Forsyth 2020; Sennet 2020; Pasqui, Vitillo 2020; Moccia, Sepe 2021; Martinez, Short 2021), though little aware of past disciplinary tradition. At the same time, cities from all over the world have been confronting with several transformations and have put in place actions to limit the difficulties encountered in everyone's daily life, which concern a range of aspects, from the individual and family organization, to the health organization, and the use and organization of cities, both in terms of spaces and facilities.

The authors discuss whether the recent debate and the actions implemented have placed health at the center of the planning discourse in an innovative way or rather have underlined a return to the origins, taking up from planning history, especially from the modern town-planning era, traditional topics and approaches.

This tradition concerns the role that health has played in orienting modern town-planning since its origins, as also pointed out by some urban historians (Ashworth, 1954; Benevolo, 1963) who argued that the statutory town-planning is an evolution and development of the sanitary rules and regulations.

The contribution is a theoretical survey conducted through a literature review alongside the inter- 
disciplinary research project Coltivare_salute.com, funded by Politecnico di Milano, alongside the program "Polisocial Award 2020" which has the objective to investigate the community health services in Italy and their implications in both sanitary organization and urban planning and design (Ugolini, forthcoming). It is structured in three sections. The first section describes significant episodes in the planning history focusing on two national contexts, Italy and England, for demonstrating that health and sanitary objectives have oriented town planning since its origins, dated back in late XIX century. Moreover, after the II World War, the issue of health faded into the background, though it entered in a marginal way in some studies and municipal planning policies. In the section 2, we highlight a resurgence in the last $30-40$ years of an interest in well-being and quality of life by planning policies in Europe and, more recently, by studies which redevelop the hygienist approaches. In the section 3 , we examine the contribution of cities in reacting to the Covid-19 pandemic by presenting a number of planning strategies, policies and actions implemented by local governments, that have been experimenting with new forms of urban proximity. The final section discusses the extent to which the global pandemic has brought innovations to the debate regarding the relationship between health and planning.

\section{Planning cities for answering to health problems}

According to Benevolo (1963), modern town-planning is the outcome of a fertile combination between techniques and ethics for correcting and repairing the imbalances of the industrial city. In itself problems of hygienic shortage, water supply, absence of sewers, accumulation of waste, excessive building density, lack of ventilation, absence of open spaces, overcrowding and high mortality are concentrated. From the mid-1800s, this sanitation deficit was no longer accepted as inevitable. A "confidence in a better future" begun to spread in Europe (Benevolo, 1963: 53) and a range of laws and devices were put in place to find a remedy for what Calabi (1979) named the "evil-city".

In England, before the rest of Europe (Geddes, 1915), the urbanization processes generated by the development of industry led to a rapid demographic increase and a reduction of the average expectation of life at birth. Since 1831 numerous cholera epidemics took place in the country and they pushed the governmental intervention on three fronts which, according to the authors, characterize the English context.

Firstly, commissions of inquiry were set up to survey and measure the conditions of the working class and their dwellings. In fact, the epidemiological study of 1854 identified the sources of cholera and led to the construction of the main London sewer system, completed in 1865 (Benevolo 1963; Johnson 2006). In England, this attention to produce surveys and give recommendations to decision-makers will be a constant over time.

Secondly, a number of philanthropic and entrepreneurial initiatives intervened both in degraded and unhealthy urban neighbourhoods and via new expansions, to improve the housing conditions of workers. These limited interventions were geographically circumscribed in urban and rural areas and they paid attention to preserve public budgets as well as the private property, ensuring a commercial return for developers (Ashworth 1954).

Thirdly, the creation of a hygienic legislation led to the construction of the housing areas just mentioned and the provision of the needed infrastructural services: water networks, sewers, solid waste disposal, road paving and, successively, collective facilities such as schools, hospitals and open spaces for recreation. These were sanitary engineering works which responded to the hygienic deficiencies of cities. The transition from the sanitary legislation to the town-planning one, the latter endowed with a comprehensive and systematic character, happened without discontinuity when coordinated action schemes will be needed to intervene on existing urban fabric or to create new settlements. 
The $1^{\text {st }}$ Public Health Act (1847) aimed to improve sanitary conditions in the most densely-inhabited neighbourhoods and placed under a single management body the water network, sewers, drainage, sanitation, new pavement and road maintenance, public gardens and the regulation of slaughterhouses and rental houses. With the $2^{\text {nd }}$ Public Health Act (1875), prescribing building heights and distances and defining the urban and rural health districts, and the Housing of the working-class Act (1890), instead focusing on healthcare and subsidized construction, the boundary between health regulations and urban planning rules became more and more nuanced.

Thanks to these interventions, in the late $19^{\text {th }}$ century English cities had adequate essential services (water supply and sewers) and a good provision of public parks. These conditions favoured a shift from the action on distinct services towards the radical transformation of the city. The "sanitary movement" reforms gave its way to a "movement for town improvement" (Ashworth 1954: 77) which, on the one hand, regenerated the central districts and, on the other, led people to move in the suburbs, areas characterised by a healthier and low-congestion living environment. The Garden City movement became the promoter and supporter of this decentralization proposal, which gave rise in the United Kingdom and abroad to the creation of suburbs and new towns.

Also in Italy the definition of modern town-planning regulations started from a health crisis. In fact, the law for city rehabilitation was approved to address the dramatic cholera epidemic that hit Italy in 1884-1885.

Although the infections had a ten-year recurrence, on this occasion some proposals elaborated in past years came to maturity. Quarantines and sanitary cordons were considered obsolete and they were supplanted by vaccinations and "the establishment of a capillary network of controls and prevention tools [..., and] a network of local landmarks" (Zucconi, 1989: 31). The intervention on the health system was accompanied by town-planning and sanitation measures.

The Law for the rehabilitation of Naples, later extended to the whole peninsula, established the creation of new sewers (built in 1892) and the water network, the demolition and reconstruction of buildings, the rectification of roads and the construction of new settlements in the suburbs. It also identified the local plan as the administrative device to be elaborated where "the health conditions of dwellings make its need manifest" (art. 18, quoted in Zucconi, 1989: 49).

The Code of Hygiene and Public Health (1888) among its measures established that the mayor had the right to declare uninhabitable an unhealthy or unsafe dwelling, and to declare new buildings habitable, based on hygiene requirements.

In 1893, a financial crisis and serious irregularities interrupted the work. This started again only few years after and in reduced forms, bringing to conclusion the facades of the Rettifilo (Corso Umberto I), which however hide the decay of the so-called "bassi" neighborhoods of Porto, Pendino, Mercato and Vicaria (Russo, 1960).

It is relevant to highlight that the failure of the Naples rehabilitation plan had consequences for the evolution of Italian town-planning (Zucconi, 1989). In fact, the positivist investigations of hygienists on sanitary conditions, on the one hand, supported the interventions, and on the other justified the demolition of the historic centre. Similar arguments supported the evictions in Genoa, Milan and Turin. Furthermore, the restoration or sanitation techniques (road alignments, demolitions/reconstructions, network services), as well as expropriation and building configurations aimed at public hygiene became undisputed tools and parameters, established on objective bases, and became part of the building regulations. Hence, the measures of the three-year period 1885-1888 marked a strict relationship between health and intervention on the physical city, indicating that the transformation of the urban space appears as "a technically treatable question" (Zucconi, 1989: 20).

\section{○ isocarp}


Thanks to the fertile link between health and urban planning, the transition from the monument-city to the service-city took place at the end of the $19^{\text {th }}$ century (Gravagnuolo, 1991). The English and Italian cases show that the first town-planning regulations and devices were oriented to solve endemic hygienic problems, and the town-planning discipline was born from the need to alleviate the unhealthiness generated by urbanization processes. Furthermore, it should be recognized that these health-related legislative measures, together with other instances, made it possible to carry out major transformations also in other European and North American cities. For example, in Paris, Hausmann's interventions were allowed precisely by the law for the rehabilitation of unhealthy houses of 1850, which extended the expropriation from public works to the rehabilitation of unhealthy neighbourhoods.

Lastly, it is useful to mention an Italian episode that highlights a loss of interest of the topic of health in urban planning.

After the II World War, in Italy there were still unhealthy urban pockets, of backwardness and misery, in the smaller towns and marginal areas. These contexts become the field of activity for territorial planning, together with statistical, economic, social and anthropological studies (Camera dei Deputati, 1951-1954). In this phase, the relationship between health and urban planning turned towards the social sciences. In Grassano in 1954, Quaroni investigated the different living conditions in relation to the physical forms in which they occur (Lanzani, 1996). In the local plan of Assisi of 1955-1958, the survey on the conditions of homes and families took into consideration hygiene and health parameters with respect to the environmental conditions, basic services, dwellings and family composition. These parameters are able to identify the extent, spatial distribution and priority of the redevelopment interventions (Astengo, 1958). These are relevant experiments of morphological, urban and social analysis with a focus on the health of families, communities and the built environment, though little replicated in future planning.

\section{From health to wellbeing}

With the rise of living standards in Western countries, the topic of health has waned in urban planning. During the last 30/40 years in Europe, the interest in well-being and quality of life has increased.

During the 1990s, in various European countries, a range of public policies were introduced to reorganize the times of cities for promoting individual and social wellbeing (Mareggi, 2002). Started in the 1980s, urban time policies were centred on the coordination of urban timetables, particularly those of public and private services, in order to make citizens' daily life easier. In Italy, hundreds of municipalities, few metropolitan cities and networks of small and medium towns have been involved to promote these kinds of policies. The time-space approach has been disseminated also in other European countries: large cities and companies in France, few medium cities and landers in Germany, Barcelona and some other cities in Spain, more than one hundred projects in the Netherlands. In 2010 the Congress of Local and Regional Authorities of the Council of Europe has adopted a recommendation (Rec 295/2010) and a resolution (Res 313/2010) in order to foster local time policies (Mückenberger, 2011).

The policies produced have different relevance regarding services such as: synchronization/desynchronization of school timetables, coordination of the shops' opening hours, cooperation with the District Social Plans and the plans which define the system of services, smart working, harmonization of the events' calendar, coordination of the tourist services, sustainable mobility for the reduction of pollution generated by transports, accessibility and temporal usability - also online - of services. They also have different spatial scales (a neighbourhood, an urban area or the entire city) and different impacts on citizens and on the organization of services.

These policies started from individual problems of work-life balance but looked for urban-scale solutions for the services offered to citizens. In fact, they acted on the urban and social environment and on the timetable of public and private services to enhance the opportunity of choice of citizens. Indeed, these 
policies referred to a collective action as local governments treated individual and everyday problems with joint responses attentive to different citizens' target, trying to favour individual wellbeing.

In the same years, solicited by the Ottawa Charter (1986) of the World Health Organization (WHO), the Healthy cities movement was established. This European network was launched in 1987-88 and in 2015 it counted 1400 European cities and over 30 national networks (Tsouros, 2015). This movement focuses on the influence of the urban environment on health, which cannot be guaranteed just by health services. According to the model by Whitehead and Dahlgren (1991), the "determinants of health" are a complex system that concerns the predetermined individual components (age, sex and hereditary factors) and other four levels: individual behaviour and lifestyle factors, social and community influences, living and working conditions, and general socio-economical, cultural and environmental factors. These levers of people's health have allowed to promote the emergence of the so-called healthy urban planning (Barton and Tsourou, 2000), which pushes cities to develop and strengthen the integration between different policies and sectors of the public administration to improve health and quality of life in the urban environment.

The interventions emerged so far range on many fronts: the regeneration of existing settlements; the "compact growth" promoting proximity; the "focused decentralization" implementing self-sufficient poles in terms of job and services; the "linear concentration" along the main public transport corridors; the transportation reducing car use and promoting walking, cycling and transit; the mixed-use neighbourhoods; the open spaces favouring ecology, sociability and individual motility (D'Onofrio and Trusiani, 2018). By summarizing a vast literature, the authors point out the strengths and the limitations of this movement, including the weak capacity - if not in a few cases, such as in UK - to influence urban plans, and the partiality, fragmentation and contradiction of urban redevelopment interventions (such as in Scotland). However, the collective work of the movement has indicated the need to move from small-scale and demonstration projects to long-term, integrated and cross-sectoral policies, as well as the strategies of the Health Impact Assessment (such as in Finland from 1994).

The two movements, Time of the city and Healthy city, marked a shift of interest in urban planning towards the treatment of well-being in cities (Duhl, Sanchez, 1999; Mückenberger, 2011). They have in common the fact that they were both real-world wellbeing laboratories for developing and incubating innovative initiatives and exploring the role of urban environment in determining the conditions of well-being, assuming it as at the top of a pyramid of health gradient (Barton, Tsourou, 2000). Finally, they recognized the local level as a privileged space for experimentation and the local governments having a key-role in creating supportive environments for healthy living.

If the two movements shown above focused on health as wellbeing and quality of life, a line of studies with a scientific perspective and roots in medical studies has recently emerged: the urban health studies. These start from the sanitary sector and relate health problems to the impact of the physical and social environment on individuals. Thus, urban environment is observed through "health prism or lens" which requires researchers to use a range of diagnostic assessments as well as intervention approaches. Also, it includes adequate indicators and scales and uses quantitative modeling that helps to estimate risks and benefits (Fehr, Capolongo, 2016).

\section{Cities reacting to the heath emergency}

In 2020, the pandemic has brought the issue of health back to the center of the debate on the future of cities. Although in the last 20 years several pandemics spread around the world (e.g., the SARS in 2002 or the Ebola in 2014), the global reach and the degree of infectivity and mortality of the Covid-19 pandemic have deeply impacted the development of cities. The interventions implemented respond to the objective of adapting cities to the new health risk, promoting new forms of proximity in the daily life of citizens, and involve various operational areas, ranging from the redesign and re-functionalization of urban spaces, 
especially public ones, to the adaptation - and in some cases the profound transformation - of the forms of management and organization of public services and facilities, with particular attention to sanitary services.

A model that gained a wide success and diffusion in the city strategies put in place by local authorities to react to the pandemic is the 15-minute city model, a concept developed by $C$. Moreno and introduced in the campaign "Paris en commun" for the re-election of the mayor of Paris, A. Hidalgo. According to this model, citizens' basic needs such as work, shopping, health and recreation should be available within few minutes from their home (Weng et al., 2019; Pisano, 2020; Moreno et al., 2021). Though the model is not fully novel, as some of its assumptions were already present in 1920s' town planning (Howard, 1922; Perry, 1929) and some of its features were previously applied in some recent city strategies and plans (e.g., Melbourne, Portland and Singapore), it has surely found a comprehensive application in Paris. The objective is to encourage citizens to reduce long-distance displacements and to use functions and services present in their neighbourhood, and to access them by foot or bicycle. Moreover, emphasis is placed on establishing in public and semi-public spaces different functions, making sure that they are used throughout the day, and on encouraging and supporting small stores to settle down in neighbourhood streets such as food groceries, bookshops and cafes (O'Sullivan, 2020).

The success of this model is witnessed by its extensive world-wide application, even though with significant variation. One example is the case of London, where the mayor has launched in May 2020 the "Streetspace Plan" which gave space to new cycle lanes and wider pedestrian pavements to enable social distancing and reduce the pressure on metro and buses (London Assembly, 2020). A more strategic-oriented case is found in cities like Milan and Birmingham. In the first case, the Municipality released in April 2020 the "Milan 2020 Adaptation Strategy", a detailed document which draws the recovery phase of the city after the pandemic by directly referring to the 15-minute city model, both in terms of balancing the interneighbourhood differences related to number of services, applying a notion of territorial cohesion already part of local policy discourses (Lazzarini, Pacchi, 2021), and of differentiating the temporal organisation of public services, with the desynchronization of entry and exit times (Comune di Milano, 2020). In the case of Birmingham, the City Council launched in January 2021 the "Our Future City Plan. Central Birmingham 2040" which directly refers to the model by proposing a vision for the city made of a network of 15-minute neighbourhoods. It uses the image called "City of Centres" to underline the need to promote a network of centres and neighbourhoods, each with its own specialism and character, offering a range of amenities for local living and working (Birmingham City Council, 2021). Another interesting case is found in Oakland, where the city administration has elaborated the "Oakland Slow Streets", a program to support safe physical activity and alleviate overcrowding in parks and public spaces by closing to traffic certain local streets. The program is made of two design devices, the "Slow Street Corridors", soft street closures to give local streets more space for physically-distant walking, biking, and other physical activities and to alleviate crowding on sidewalks, and the "Slow Street Essential Places", temporary traffic safety improvements at pedestrian crossings to enable a safe access to essential services (City of Oakland, 2020). A more radical approach is taken by the "2024 Urban Mobility Plan" of Barcelona which explicitly takes the commitment to reduce by 2024 the use of private vehicles from 26 to 18\%, favouring a mobility based on walking and public transport (Ajuntament de Barcelona, 2020). One of the solutions adopted to achieve the plan's objective is the Superblock model, an innovative land-use intervention applied to the Cerdà's ensanche made of an orthogonal grid pattern of approximately 400sqms cells, which allows to provide the city with a network of local roads accessible primarily to active transport (walking and cycling) and secondarily to residential traffic with a maximum speed of $20 \mathrm{~km} / \mathrm{h}$ (Rueda, 2018). As reported by Mueller et al. (2020), there are currently 3 Superblocks implemented in the city, while other 6 are planned by the City Council and the extensive application of model foresees the creation of public green open spaces in the areas reclaimed by cars. 
As far as the new forms of organization of health services are considered, a significant case is the new Strategic Plan of the Metropolitan City of Turin, "Turin, Augmented Metropolis" (2021-2023), which directly refers to the contents of the Italian Recovery and Resilience Plan (NRRP), approved by Parliament in early 2021 to manage the EU funding of the "NextGenerationEU" recovery program (Presidenza del Consiglio dei Ministri, 2021). The interest of the Plan lies in the strengthening of the territorial dimension of health services, ensuring a suitable access throughout the metropolitan area (Metropolitan City of Turin, 2021). The plan puts in place two devices, the "health centres" (Brambilla, Maciocco, 2016) and the "community nurses", working synergically in the territory, in order to guarantee, on the one hand, to local communities a health facility serving as an easily accessible reference point for patients with minor pathologies and, on the other hand, continuous and quality home care for fragile subjects with chronic diseases and for people forced to stay at home, thus preventing the risks of isolation. The widespread and adaptive (also during emergency phases) localization of operators and community health facilities in the territory, rather than in major poles (specialized hospitals) envisaged by the Turin Plan responds to the need to shape a stronger relationship between medicine and the community. This relationship, indicated for the development of health organizations, can also become a guideline for the planning of public services.

Therefore, those mentioned are planning proposals that intervene mainly through actions focusing on the management of services and open spaces, rather than through land-use policies and plans. Only in a marginal way, they re-draw the city as a whole and the healthy city principles and tools become mainstream in statutory planning strategies and plans.
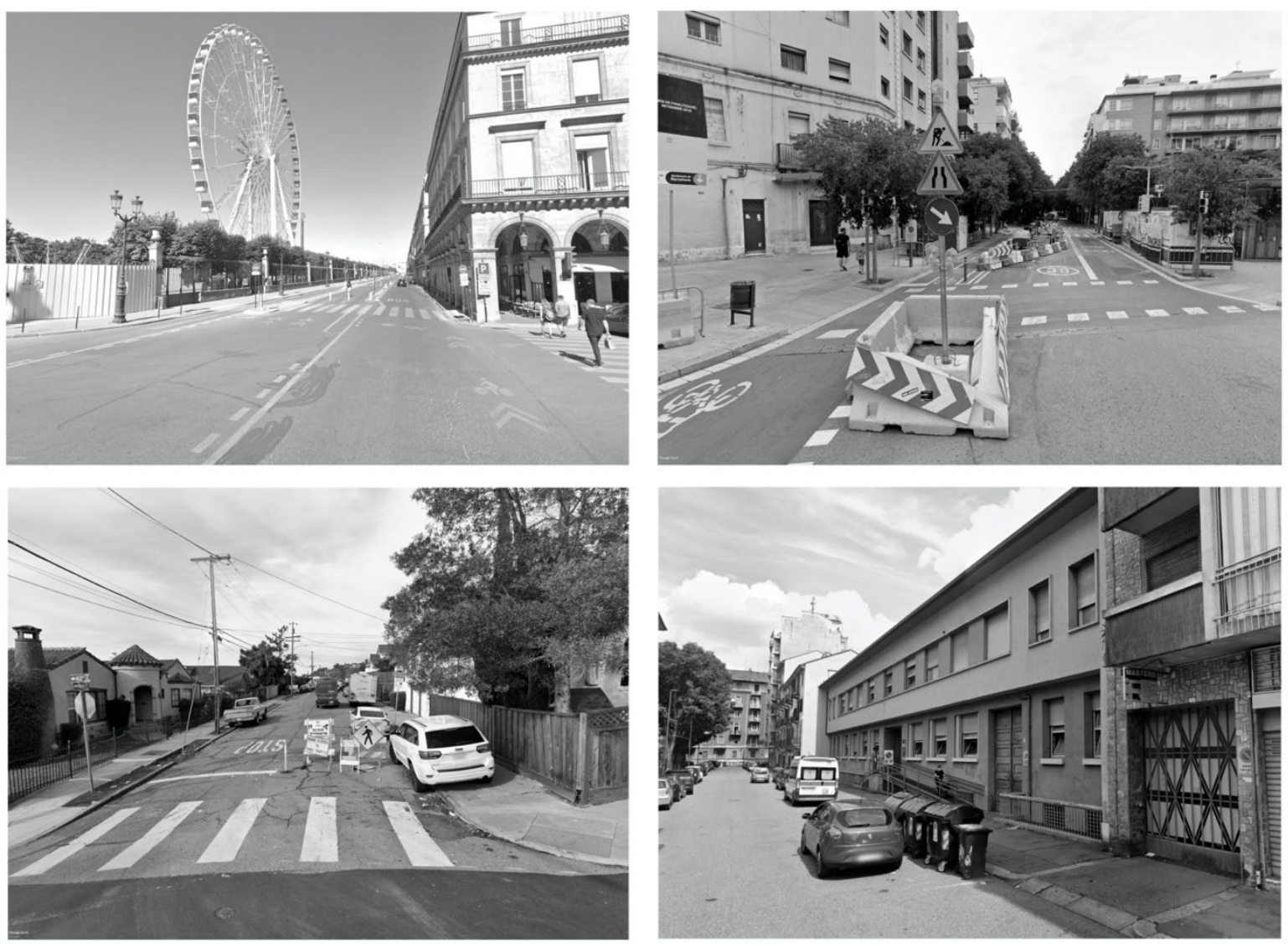

Figure 1. From top left to bottom right. A view of Rue de Rivoli in Paris after the creation of a multi-lane biking highway. One of the entrances to Les Corts Superblock in Barcelona. The "Ney Ave Slow Street" in Oakland (California). One of health centres ("Case della Salute") in Turin (Italy). Source: Google Earth. 


\section{Conclusion}

The evolutionary framework outlined regarding the relationship between health and urban planning shows the transition from an initial phase in which the first has a propulsive role for the latter (1850-1900) to a second phase in which health problems subside (post-1945). This was followed by a period of innovations in which urban planning has interpreted the environment as a determining factor for health (post-1990). Precisely this phase gives concreteness in the process of city transformation to the new public health paradigm proposed by the WHO (Constitution, art. 1, New York, 1946), in which "health is a state of complete physical, mental and social wellbeing and not merely the absence of disease or infirmity". Today the pandemic has re-proposed the centrality of the city-health relationship, which brings into play in urban planning health-related components, environmental aspects and aspects of construction of a cohesive and aware community. Do these recent proposals, and the related debate triggered by the pandemic, bring innovations or revive and enhance the acquisitions of urban planning of the modern origins and of the last $30 / 40$ years?

The measures for managing the pandemic (sanitary cordons, vaccinations, etc.), as well as the launch of ambitious urban projects that question consolidated frameworks, show parallels with some attitudes and interventions of the second half of the $19^{\text {th }}$ century. Similarly, the planning of health facilities organized in a territorially balanced way, envisaged in the Italian NRRP, presents similarities with the proposal to establish a capillary network of local sanitary control and prevention facilities, suggested by the Italian health and urban renewal legislation of 1885-1888. Here, the innovation concerns a greater link with the local community and the integration between different services.

Moreover, the importance of the local scale of intervention and of the local governments managing it, is relevant today as it was in the past strategies, actions and planning tools discussed in previous sections.

Finally, the health crisis has reopened the debate on the compact city model, already object of discussion in its contribution to the environmental sustainability (Kjærås, 2021), re-proposing for the post-pandemic the spatial model of self-sufficient decentralization and the 15-minute city. Also in this case historical elements are present, as many are the relationships with the XX century's Garden City movement or the decentralized centralization of the Healthy City movement. Nevertheless, the reflections concerning the critical relaunch of these models seem to be scarce, while the proposals appear to be driven more by necessity than by a thoughtful recovery of past experiences.

\section{Credits}

This work is the product of a joint reflection among the authors. Introduction, sections 2 and 3 are attributed to M. Mareggi. Section 4 is attributed to L. Lazzarini. Section 5 was written by both authors.

\section{References}

Ajuntament de Barcelona (2020) Plan de la Mobilitat Urbana 2024. Document per a la Aprovació Inicial [online]. Available at: https://www.barcelona.cat/mobilitat/en/news-and-documents/initialapproval-2024-urban-mobility-plan (Accessed: 20 August 2021).

Ashworth, W. (1954) The genesis of modern British town planning. London: Routledge e Kegan Paul Lto.

Astengo, G. (ed.) (1958) 'Il Piano regolatore generale di Assisi', Urbanistica, 24-25, pp. 10-132.

Barton, H. and Tsourou, C. (2000) Healthy Urban Planning. London-New York: Spon press.

Benevolo, L. (1963) Le origini dell'urbanistica moderna. Rome-Bari: Laterza [English edition: (1971) The origin of modern town planning. Cambridge-London: MIT Press]. 
Birmingham City Council (2021) Our Future City Plan. Central Birmingham 2040. Shaping our city together [online] Available at:

https://www.birmingham.gov.uk/info/20008/planning_and_development/2303 /our_ future_city_plan_ofcp_-_central_birmingham_2040 (Accessed: 7 August 2021).

Brambilla, A. and Maciocco, G. (2016) La Casa della Salute. Innovazione e buone pratiche. Rome: Carocci.

Calabi, D. (1979) II male città. Diagnosi e terapia. Rome: Officina edizioni.

Camera dei Deputati, Repubblica Italiana (1951-1954) Commissione parlamentare d'inchiesta sulla miseria in Italia e sui mezzi per combatterla [online]. Available at:

https://archivio.camera.it/patrimonio/main-page/commissione-sulla-miseria-italia-e-sui-mezzicombatterla-1951-1954 (Accessed: 14 August 2021).

Città Metropolitana di Torino (2021) Torino Metropoli Aumentata. Piano Strategico Metropolitano 20212023, 18 February.

City of Oakland (2020) Oakland Slow Streets Interim Findings Report, September 2020 [online]. Available at: https://www.oaklandca.gov/documents/oakland-slow-streets-interim-findings-reportseptember-2020-1 (Accessed: 20 August 2021).

Comune di Milano (2020) Milano 2020. Strategia di adattamento, 14 April 2020 [online]. Available at: https://www.comune.milano.it/documents/20126/95930101/Milano+2020.++Strategia+di+adattam ento.pdf/c96c1297-f8ad-5482-859c-90de1d2b76cb?t=1587723749501 (Accessed: 7 August 2021).

D'Onofrio, R. and Trusiani E. (2018) Urban Planning for Healthy European Cities. Berlin: Springer.

Duhl, L.J. and Sanchez, A.K. (eds.) (1999) Healthy Cities and the City Planning Process. A Background Document on Links Between Health and Urban Planning, Copenhagen: WHO.

Fehr, R. and Capolongo, S. (eds.) (2016), “Healing environment and urban health", E\&P Epidemiologia e prevenzione, 40(3-4), pp. 151-152 [online]. Available at: doi: 10.19191/EP16.3-4.P151.080 (Accessed: 8 August 2021).

Forsyth, S. (2020) What role do planning and design play in a pandemic?. Department of Urban Planning and Design, Harvard University Graduate School of Design [online]. Available at: https://www.gsd.harvard.edu/2020/03/how-to-mitigate-the-impact-of-an-epidemic-andprevent-the-spread-of-viral-diseases-a-guide-for-designers/ (Accessed: 20 August 2021).

Geddes, P. (2015) Cities in evolution. London: Williams \& Norgate.

Gravagnuolo, B. (1991) La progettazione urbana in Europa. 1750-1960. Bari: Laterza.

Howard, E. (1922) Garden Cities of Tomorrow. London: Swan Sonnenschein \& Co.

Johnson, S. (2006) The Ghost Map: The Story of London's Most Terrifying Epidemic and How it Changed Science, Cities and the Modern World. New York: Penguin.

Lanzani, A. (1996) Immagini del territorio e idee di piano 1943-1963. Milan: Franco Angeli.

Lazzarini, L. \& Pacchi, C. (2021) Local narratives and spatial configurations of territorial cohesion: some evidences from COHSMO Project. DAStU Working Paper Series, n. 07/2021 (LPS.21).

London Assembly (2020) Mayor's bold new Streetspace plan will overhaul London's streets [online]. Available at: https://www.london.gov.uk/press-releases/mayoral/mayors-bold-plan-willoverhaul-capitals-streets (Accessed: 19 August 2021).

Mareggi, M. (2002) 'Innovation in Urban Policy: The Experience of Italian Urban Time Policies', Planning Theory and Practice, 3(2), pp. 173-194. 
Martinez, L. and Short, J.R. (2021) 'The Pandemic City: Urban issues in the time of Covid-19', Sustainability 13, 3295 [online]. Available at: doi.org/10.3390/su13063295 (Accessed: 8 August 2021).

Moccia, F.D. and Sepe, M. (2021) Benessere e salute delle città contemporanee. Rome: Inu Edizioni.

Moreno, C., Allam, Z., Chabaud, D., Gall, C., Pratlong, F. (2021) 'Introducing the "15-Minute City": Sustainability, Resilience and Place Identity in Future Post-Pandemic Cities', Smart Cities 4, pp. 93-111 [online]. Available at: doi.org/10.3390/smartcities4010006 (Accessed: 24 August 2021).

Mückenberger, U. (2011) 'Local time policies in Europe?', Time \& Society, 20(2), pp. 241-273.

Mueller, N., Rojas-Rueda, D., Khreis, H., Cirach, M., Andrés, D., Ballester, J., Bartoll,X., Daher, D., Deluca, A., Echave, C., Milà, C., Márquez, S., Palou, J., Pérez, K., Tonne, C., Stevenson, M., Rueda, S., Nieuwenhuijsen, M. (2020) 'Changing the urban design of cities for health: The superblock model', Environment International, 134, pp. 1-13.

O'Sullivan, F. (2020) 'Paris Mayor: it's time for a "15-minute city"', Bloomberg CityLab [online]. Available at: https://www.bloomberg.com/news/articles/2020-02-18/paris-mayor-pledges-a-greener-15minute-city (Accessed: 13 August 2021).

Pasqui, G. and Vitillo, P. (eds.) (2020) 'Città, territori, urbanistica al tempo delle pandemie', Urbanistica Informazioni, 287-288, pp. 10-31.

Perry, C. A. (1929) 'La pianificazione del vicinato e della comunità' in Sica, P. (1980) Antologia di urbanistica. Dal Settecento ad oggi. Bari: Laterza.

Pisano, C. (2020) 'Strategies for post-COVID Cities: an insight to Paris En Commun and Milano 2020', Sustainability, 12(5883).

Presidenza del Consiglio dei Ministri (2021) Piano Nazionale di Ripresa e Resilienza \#NextGeneration/talia [online]. Available from: https://innovazione.gov.it/notizie/articoli/next-generation-italiaapprovato-il-piano-del-governo/ (Accessed: 20 August 2021).

Rueda, S., 'Superblocks for the design of new cities and renovation of existing ones. Barcelona's case' in Nieuwenhuijsen, M., Khreis, H. (eds.) (2018) Integrating Human Health into Urban and Transport Planning, Switzerland: Springer, pp. 135-154.

Russo, G. (1960) II risanamento e l'ampliamento della città di Napoli. Naples: L'Arte Tipografica.

Sennet, R. (2020) 'Cities after coronavirus: how Covid-19 could radically alter urban life', The Guardian, 26 March [online]. Available at: https://www.theguardian.com/world/2020/mar/26/life-aftercoronavirus-pandemic-change-world (Accessed: 7 August 2021).

Tsouros, A.D. (2015) 'Twenty-seven years of the WHO European Healthy Cities movement: a sustainable movement for change and innovation at the local level', Health Promotion International, 30(S1 i3), pp. 13-17.

Ugolini M. (forthcoming) ‘Case della Salute: condizioni di fragilità e occasioni di rigenerazione sociale e urbana', Territorio, special issue.

Weng, M., Ding, N., Li, J., Jin, X., Xiao, H., He, Z., Su, S. (2019) 'The 15-minute walkable neighborhoods: Measurement, social inequalities and implications for building healthy communities in urban china', J. Transp. Health 13, pp. 259-273.

Whitehead, M. and Dahlgren, G. (1991) 'What ca new do about inequities in health', The Lancet, 338, pp. 1059-1063.

Zucconi, G. (1989) La città contesa. Dagli ingegneri sanitari agli urbanisti (1885-1942). Milan: Jaca Book. 